\title{
Penerapan Metode Simple Additive Weighting Sebagai Sistem Pendukung Keputusan Dalam Evaluasi Kinerja Program Studi Berbasis Web
}

\author{
Erliza Yubarda ${ }^{1}$, Srititi Handayani ${ }^{2}$ \\ 1,2)Program Studi Manajemen Informatika, AMIK Mitra Gama \\ Jl. Kayangan No.99 Duri - Riau \\ Email: erlizayubarda1984@gmail.com
}

\begin{abstract}
ABSTRAK
Mutu suatu program studi disuatu perguruan tinggi perlu ditingkatkan secara berkelanjutan karena meningkatnya persaingan. Penelitian ini membahas tentang evaluasi kinerja program studi sebagai pendukung keputusan mengukur kinerja program studi berdasarkan kriteria yang telah ditentukan, sebagai bahan evaluasi bagi perguruan tinggi untuk perkembangan program studi kedepannya. Penelitian ini menggunakan Fuzzy MADM untuk mencari alternatif optimal dari sejumlah alternatif dengan kriteria tertentu dan menentukan nilai bobot untuk setiap atribut kemudian dilanjutkan dengan proses perangkingan evaluasi program studi menggunakan Metode Simple Additive Weighting (SAW), yaitu sering dikenal dengan metode penjumlahan terbobot. Metode ini akan melakukan perangkingan terhadap alternatif yang telah ditentukan dimana hasil perangkingan tertinggi akan keluar menjadi hasil evaluasi yang terbaik. Alternatif tersebut diuji dengan 17 (tujuh belas) kriteria dengan masing-masing variabelnya mempunyai nilai pembobotan yang berbeda-beda. Adanya perancangan sistem evaluasi kinerja program studi berbasis web ini dapat dijadikan sebagai sistem pendukung keputusan oleh perguruan tinggi dalam melakukan evaluasi program studi secara berkala.
\end{abstract}

Kata kunci: Fuzzy MADM, Metode SAW, Evaluasi Program Studi, Kinerja, Kriteria.

\section{ABSTRACT}

The quality of a program of studies at a college needs to be improved on an ongoing basis due to increased competition. This study discusses the evaluation study aimed to measure the performance of the program of study based on predetermined criteria, evaluation materials for the college for the future course development. This study uses fuzzy MADM to find alternative optimal from a number of alternatives to certain criteria and determine the weightings for each attribute and then proceed with the course evaluation using Simple Additive weighting (SAW) method, which is commonly known as the weighted sum method. This method will do rangking the alternatives that have been established where the results will be out highest ranking be the best

UNITEX Vol 11 No.2 Juli - Desember 2018 | p-ISSN 2089-3957 | e-ISSN 2580-2585 
evaluation. Alternatives were tested with 17 (seventeen) criteria with each variable has a value different weighting. The design of a study program performance evaluation system can be used as a decision support system by universities in periodically evaluating study programs.

Keywords: Fuzzy MADM, SAW Method, Evaluation of Program Study, Performance Criteria

\section{Pendahuluan}

Pentingnya pengukuran kinerja tidak hanya diperlukan dan dilakukan dalam dunia bisnis tetapi juga dalam dunia pendidikan. Demikian pentingnya pengukuran kinerja dalam pengelolaan perguruan tinggi atau dunia pendidikan, maka RISTEKDIKTI memasukkannya dalam format manajemen baru yang bertujuan untuk meningkatkan kualitas pendidikan secara berkelanjutan. Demikian banyak dan kompleknya permasalahan yang ada, maka perguruan tinggi berusaha mengambil langkah-langkah prioritas dalam menyelesaikan permasalahan untuk meningkatkan kinerjanya. Untuk mengukur tingkat keberhasilan, efisiensi, dan efektivitas kegiatan yang dilaksanakan, diperlukan sebuah sistem evaluasi kinerja program studi. Evaluasi kinerja program studi salah satu bagian kegiatan penjaminan mutu dalam proses penetapan dan pemenuhan standar mutu serta pengolahan secara konsisten dan berkelanjutan. Evaluasi kinerja program studi merupakan alat untuk melihat standar mutu yang telah ditetapkan pada dokumen akademik telah dilaksanakan oleh program studi. Jaminan mutu di perguruan tinggi dimana salah satunya adalah program studi hanya berupa informasi yang belum tertata dalam bentuk dokumentasi yang baik karna informasi tentang evaluasi kinerja program studi hanya berupa informasi data yang dimasukkan ke dalam Laporan Evaluasi Program Studi Berbasis Evaluasi Diri (EPSBED) yang tiap semesternya dilaporkan pada DIKTI, sehingga informasi tentang evaluasi kinerja program studi di akademik masih belum bisa didapatkan secara menyeluruh karena data yang diperlukan masih tersebar di beberapa bagian yang berbeda sehingga menghadapi banyak masalah dari berbagai sisi mulai dari mahasiswa, dosen, kurikulum, suasana akademik termasuk sarana dan prasarana yang tersedia.

Penelitian ini dibatasi pada evaluasi kinerja program studi menggunakan Fuzzy Multiple Attribute Decision Making (FMADM) dan metode yang digunakan adalah Metode Simple Additive Weighting (SAW) dalam penyelesaian masalah yang dihadapi, meliputi data mahasiswa, data dosen dan data proses belajar mengajar. Aplikasi sistem informasi berbasis web yang dihasilkan akan digunakan sebagai pendukung dalam pengambilan keputusan yang berhubungan dengan evaluasi kinerja program studi.

UNITEX Vol 11 No.2 Juli - Desember 2018 | p-ISSN 2089-3957 | e-ISSN 2580-2585 


\section{Sistem Penunjang Keputusan}

Sistem Penunjang Keputusan merupakan salah satu produk perangkat lunak yang dikembangkan secara khusus untuk membantu dalam proses pengambilan keputusan. Sesuai dengan namanya, tujuan dari dipergunakannya sistem ini adalah sebagai "second opinion" atau "information sources" yang dapat dipakai sebagai bahan pertimbangan sebelum memutuskan kebijakan tertentu. Sistem penunjang keputusan tidak dimaksudkan untuk mengotomatisasikan pengambilan keputusan, tetapi memberikan perangkat interaktif yang memungkinkan pengambil keputusan untuk melakukan berbagai analisis menggunakan model-model yang tersedia.

"Sistem pendukung keputusan merupakan suatu pendekatan untuk mendukung pengambilan keputusan. Sistem pendukung keputusan menggunakan data, memberikan antarmuka pengguna yang mudah, dan dapat menggabungkan pemikiran pengambil keputusan (Armadyah Amborowati, 2004)". Sistem penunjang keputusan lebih ditujukan untuk mendukung manajemen dalam melakukan pekerjaan yang bersifat analitis dalam situasi yan kurang terstruktur dan dengan kriteria yang kurang jelas, adapun tujuan dari Decision Support System (Kusrini, 2007), yaitu:

a. Membantu menajer dalam pengambilan keputusan atas masalah semi terstruktur.

b. Memberikan dukungan atas pertimbangan manajer dan bukannya dimaksudkan untuk menggantikan fungsi manajer.

c. Meningkatkan efektivitas keputusan yang diambil manajer lebih dari pada perbaikan efesiensi.

d. Kecepatan komputasi. Komputer memungkinkan para pengambil keputusan untuk melakukan banyak komputasi secara cepat dengan biaya yang rendah.

e. Meningkatkan produktivitas.

f. Dukungan Kualitas

g. Berdaya Saing

h. Mengatasi keterbatasan kognitif dalam pemrosesan penyimpanan.

\section{Fuzzy MADM}

"Fuzzy Multiple Attribut Decision Making adalah suatu metode yang digunakan untuk mencari alternatif optimal dari sejumlah alternatif dengan kriteria tertentu. Inti dari MADM adalah menentukan nilai bobot untuk setiap atribut, kemudian dilanjutkan dengan proses perangkingan yang akan menyeleksi alternatif yang sudah diberikan (Ayu Permatasari dan Sarwo Sri, 2010). "Pada dasarnya, proses MADM dilakukan melalui 3 tahap, yaitu penyusunan komponen-komponen 
situasi, analisis dan sintesis informasi (Rudolphi, 2000)". Algoritma yang dipakai dalam menyelesaikan permasalahan FMADM (Henry Wibowo, 2009) :

a. Memberikan nilai setiap alternatif (Ai) pada setiap kriteria $(\mathrm{Cj})$ yang sudah ditentukan,dimana nilai tersebut di peroleh berdasarkan nilai crisp; $i=1,2, \ldots$ m dan $\mathrm{j}=1,2, \ldots . \mathrm{n}$.

b. Memberikan nilai bobot (W) yang juga didapatkan berdasarkan nilai crisp.

c. Melakukan normalisasi matriks dengan cara menghitung nilai rating kinerja ternormalisasi (rij) dari alternatif $\mathrm{Ai}$ pada atribut $\mathrm{Cj}$ berdasarkan persamaan yang disesuaikan dengan jenis atribut. Atribut keuntungan / benefit $=$ MAKSIMUM atau atribut biaya $/$ cost $=$ MINIMUM. Apabila berupa artibut keuntungan maka nilai crisp (Xij) dari setiap kolom atribut dibagi dengan nilai crisp MAX (MAX Xij) dari tiap kolom, sedangkan untuk atribut biaya, nilai crisp MIN (MIN Xij) dari setiap kolom atribut dibagi dengan nilai crisp (Xij) setiap kolom.

d. Melakukan proses perankingan dengan cara mengalikan matriks ternormalisasi (R) dengan nilai bobot (W).

e. Menentukan nilai preferensi untuk setiap alternatif (Vi) dengan cara menjumlahkan hasil kali antara matriks ternormalisasi (R) dengan nilai bobot (W). Nilaai Vi yang lebih besar mengindikasikan bahwa alternatif Ai lebih terpilih. (Kusumadewi, 2006)

\section{Model Simple Additive Weighting Method ( SAW )}

Metode SAW sering juga dikenal dengan istilah metode penjumlahan terbobot. Konsep dasar metode SAW adalah mencari penjumlahan terbobot dari rating kinerja pada setiap alternatif pada semua atribut (Sri Eniyati, 2011)". "Metode SAW membutuhkan proses normalis fsi $^{x_{i}}$ ätrik keputusan (X) ke suatu skala yang dapat diperbandingkan dengan semu $M_{\text {Mating }}^{M} x_{i} h_{l}$ ternatif yang ada (Sri Kusumadewi At All, 2006), dimana :

$$
r_{i j}= \begin{cases}\frac{x_{i j}}{\operatorname{Max} x_{i j}} & \text { Jika j adaläh atribut keuntungan } \\ i & \text { Jika j adalah atribut biaya (cost) } \\ {\operatorname{Min} x_{i j}}_{\frac{i}{x_{i j}}} & \end{cases}
$$

UNITEX Vol 11 No.2 Juli - Desember 2018 | p-ISSN 2089-3957 | e-ISSN 2580-2585 
Dimana rij adalah rating kinerja ternormalisasi dari alternatif Ai pada atribut $\mathrm{Cj}$; $i=1,2, \ldots \mathrm{m}$ dan $\mathrm{j}=1,2, \ldots \mathrm{n}$. Nilai preferensi untuk setiap alternatif (Vi) diberikan sebagai berikut:

$$
V_{i}=\sum_{j=i}^{n} w_{j} r_{i j}
$$

Nilai Vi yang lebih besar mengindikasikan bahwa alternatif Ai lebih terpilih.

\section{Metode Penelitian}

Metodologi penelitian erat kaitannya dengan prosedur, alat, serta desain penelitian yang digunakan dalam melaksanakan penelitian. Tahapan proses dari penelitian ini mengalir sesuai dengan alur yang logis, tujuannya adalah untuk memberikan petunjuk yang jelas, teratur dan sistematis. Susunan tahapan ini sangat mempengaruhi mutu dari hasil yang akan diperoleh. Tahapan dari penelitian ini dituangkan dalam bentuk gambar kerangka konseptual yang dapat dilihat pada gambar berikut :

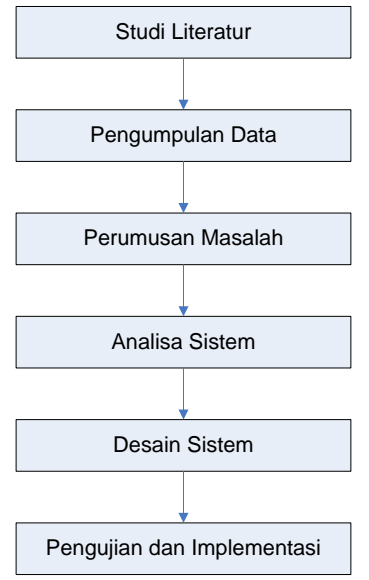

Gambar 1. Kerangka konseptual penelitian

1. Studi Literatur

Mempelajari literatur yang berkaitan dengan teori pengambilan keputusan menggunakan Fuzzy Multiple Attribute Decision Making (FMADM) dengan

UNITEX Vol 11 No.2 Juli - Desember 2018 | p-ISSN 2089-3957 | e-ISSN 2580-2585 
metode Simple Additive Weighting (SAW). Sumber literatur diambil dari jurnal, buku teks, paper, karya ilmiah, dan situs-situs penunjang lainnya.

2. Pengumpulan Data

Pada tahap ini pengumpulan data dilakukan dengan cara langsung melakukan observasi ke lapangan dan melakukan pengambilan data dengan mengajukan kuesioner. Setelah data-data tersebut dikumpulkan dan dipelajari, tindakan selanjutnya yang dilakukan adalah mencari dan memutuskan masalah-masalah yang akan dipecahkan, masalah apa yang akan dicari solusinya, masalah-masalah yang menjadi perhatian khusus, tentu saja masalah tersebut diambil berdasarkan ruang lingkup penelitian, dimana masalah yang dihadapi berkaitan dengan evaluasi kinerja program studi.

3. Perumusan Masalah

Setelah tahap pengumpulan data dilakukan, langkah selanjutnya adalah membuat perumusan masalah yang berkaitan dengan permasalahan yang dihadapi. Bagaimanakah Fuzzy Multiple Attribute Decision Making (FMADM) mampu menyelesaikan permasalahan evaluasi kinerja program studi menggunakan metode Simple Additive Weighting (SAW), berdasarkan kriteria-kriteria yang telah ditentukan.

4. Analisa dan Desain Sistem

Pada tahap ini dilakukan analisa-analisa permasalahan tentang evaluasi kinerja program studi, baik itu tentang masalah yang dihadapi, sistem yang dipakai untuk pendekatan masalah yang ada, bagaimanakah pengujian dilakukan terhadap teknik yang akan digunakan, mengapa digunakan Fuzzy Multiple Attribute Decision Making (FMADM) dengan metode Simple Additive Weighting (SAW) untuk pengembangan aplikasi sebagai pendekatan terhadap masalah yang ada. Setelah masalah-masalah tersebut dapat didefinisikan, pendekatan-pendekatandipilih berdasarkan literatur dari berbagai sumber seperti buku teks dan internet tentang teknik-teknik yang sedang digunakan saat ini dan dipilih untuk menyelesaikan permasalahan, setelah itu dibuat rancangan aplikasi evaluasi kinerja program studi menggunakan FMADM.

5. Pengujian dan Implementasi

Pada tahap ini dilakukan proses pengujian, menganalisa dan mengevaluasi hasil dari metode tersebut, termasuk menganalisa tingkat kesalahan yang dihasilkan pada tiap pengujian. Sistem setelah melalui pengujian kesalahan dapat dimplementasikan untuk dijalankan.

UNITEX Vol 11 No.2 Juli - Desember 2018 | p-ISSN 2089-3957 | e-ISSN 2580-2585 


\section{Hasil dan Pembahasan}

Analisa sistem diartikan sebagai cara untuk memahami terlebih dahulu masalah yang dihadapi oleh sistem, seperti mendefenisikan kebutuhan-kebutuhan fungsional dari sistem sehingga dapat diketahui apa saja kebutuhan-kebutuhan pemakai. Mengetahui kriteria-kriteria yang dibutuhkan dalam melakukan evaluasi kinerja program studi dan dilakukan penetapan nilai pembobotan masing-masing kriteria berdasarkan alternatif yang ada.

\section{Arsitektur Sistem Pengolahan Data}

Proses pengolahan data evaluasi kinerja program studi, arsitekturnya dapat dilihat pada gambar berikut:

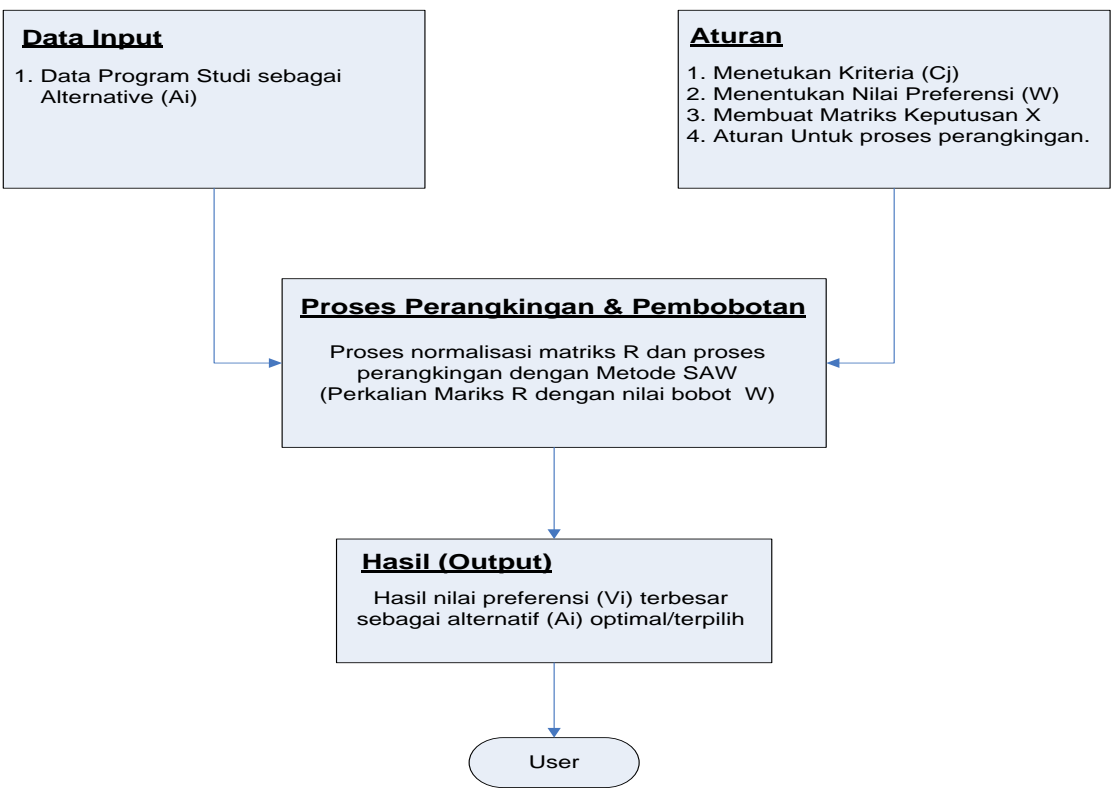

Gambar 2. Arsitektur sistem kinerja program studi

2. Penetapan Kriteria dan Nilai Bobot Preferensi (W)

Analisa dalam melakukan penelitian ini dimulai dari ditentukannya kriteria yang dibutuhkan untuk menentukan evaluasi kinerja program studi. Adapun kriterianya dan nilai bobotnya terdiri dari:

UNITEX Vol 11 No.2 Juli - Desember 2018 | p-ISSN 2089-3957 | e-ISSN 2580-2585 
Tabel 1. Rating kecocokan alternatif - kriteria

\begin{tabular}{|c|l|}
\hline Bobot & Bilangan Fuzzy \\
\hline 0 & Sangat Rendah ( SR ) \\
\hline 0,25 & Rendah ( R ) \\
\hline 0,50 & Cukup ( C ) \\
\hline 0,75 & Tinggi ( T ) \\
\hline 1 & Sangat Tinggi ( ST ) \\
\hline
\end{tabular}

Tabel 2. Kriteria dan bobot rating kecocokan

\begin{tabular}{|l|l|l|l|l|}
\hline No & Kriteria & Keterangan & $\begin{array}{l}\text { Bobot } \\
\text { Preferensi }\end{array}$ & $\begin{array}{l}\text { Jenis } \\
\text { Kriteria }\end{array}$ \\
\hline 1 & C1 & Mahasiswa Aktif & 1 & Benefit \\
\hline 2 & C2 & Jumlah Lulusan & 0,50 & Benefit \\
\hline 3 & C3 & IP Semester & 1 & Benefit \\
\hline 4 & C4 & IP Kumulatif & 1 & Benefit \\
\hline 5 & C5 & Mahasiswa DO & 0,50 & Cost \\
\hline 6 & C6 & Mahasiswa Cuti & 0,50 & Cost \\
\hline 7 & C7 & Mahasiswa Keluar dari Program Studi & 0,50 & Cost \\
\hline 8 & C8 & Mahasiswa Non Aktif & 0,50 & Cost \\
\hline 9 & C9 & Mahasiswa Lulus Seleksi & 0,75 & Benefit \\
\hline 10 & C10 & Mahasiswa Daftar Ulang & 1 & Cost \\
\hline 11 & C11 & Mahasiswa Pindahan & 0,25 & Benefit \\
\hline 12 & C12 & Dosen Tetap & 1 & Benefit \\
\hline 13 & C13 & Jenjang Pendidikan Dosen & 1 & Benefit \\
\hline 14 & C14 & Pengabdian Masyarakat & 1 & Benefit \\
\hline 15 & C15 & Penelitian Dosen & 1 & Benefit \\
\hline 16 & C16 & Jabatan Fungsional Akademik & 1 & Benefit \\
\hline 17 & C17 & Akreditasi Program Studi & 1 & Benefit \\
\hline
\end{tabular}

Untuk bobot preferensi, pengambil keputusan memberikan bobot preferensi sebagai berikut:

$\mathrm{W}=\left[\begin{array}{lllllllllllllllll}1 & 0,50 & 1 & 1 & 0,50 & 0,50 & 0,50 & 0,50 & 0,75 & 1 & 0,25 & 1 & 1 & 1 & 1 & 1 & 1\end{array}\right]$

Dalam penelitian ini yang akan menjadi alternatif yang akan diuji berdasarkan kriteria yang telah ditentukan yaitu terdiri dari 3 (tiga) buah program studi, di antaranya: 
Tabel 3. Alternatif Pengujian

\begin{tabular}{|c|l|}
\hline Alternatif & Keterangan \\
\hline A1 & Program Studi A ( Prodi A) \\
\hline A2 & Program Studi B ( Prodi B ) \\
\hline A3 & Program Studi C ( Prodi C ) \\
\hline
\end{tabular}

3. Menentukan Rating Kecocokan Matrix keputusan X

Data program studi sebagai alternatif yang telah di konversi ke bilangan fuzzy:

Tabel 4. Rating Kecocokan Setelah Pembobotan

\begin{tabular}{|c|c|c|c|c|c|c|c|c|c|c|c|c|c|c|c|c|c|}
\hline \multirow{2}{*}{ Alternatif } & \multicolumn{17}{|c|}{ Kriteria } \\
\hline & $\mathrm{C} 1$ & $\mathrm{C} 2$ & C3 & $\mathrm{C} 4$ & C5 & C6 & $\mathrm{C} 7$ & $\mathrm{C} 8$ & C9 & $\mathrm{C} 10$ & $\mathrm{C} 11$ & $\mathrm{C} 12$ & $\mathrm{C} 13$ & $\mathrm{C} 14$ & $\mathrm{C} 15$ & C16 & $\mathrm{C} 17$ \\
\hline $\begin{array}{l}\text { Prodi A } \\
\text { (A1) }\end{array}$ & $\begin{array}{l}0 \\
75\end{array}$ & $\begin{array}{l}0 \\
50\end{array}$ & $\begin{array}{l}0 \\
75\end{array}$ & $\begin{array}{l}0 \\
75\end{array}$ & 1 & $\begin{array}{l}0, \\
50\end{array}$ & 1 & $\begin{array}{l}0, \\
25\end{array}$ & $\begin{array}{l}0, \\
50\end{array}$ & $\begin{array}{l}0 \\
50\end{array}$ & $\begin{array}{l}0 \\
50\end{array}$ & 1 & $\begin{array}{l}0 \\
50\end{array}$ & 0,50 & $\begin{array}{l}0 \\
50 \\
\end{array}$ & $\begin{array}{l}0 \\
50\end{array}$ & $\begin{array}{l}0 \\
50 \\
\end{array}$ \\
\hline $\begin{array}{l}\text { Prodi B } \\
\text { (A2) }\end{array}$ & $\begin{array}{l}0, \\
50\end{array}$ & $\begin{array}{l}0 \\
50\end{array}$ & $\begin{array}{l}0, \\
75\end{array}$ & $\begin{array}{l}0, \\
75\end{array}$ & 1 & $\begin{array}{l}0, \\
50\end{array}$ & $\begin{array}{l}0, \\
50\end{array}$ & $\begin{array}{l}0, \\
50\end{array}$ & $\begin{array}{l}0, \\
50\end{array}$ & $\begin{array}{l}0, \\
50\end{array}$ & $\begin{array}{l}0, \\
50\end{array}$ & 1 & $\begin{array}{l}0, \\
50\end{array}$ & 0,50 & $\begin{array}{l}0, \\
50\end{array}$ & $\begin{array}{l}0 \\
50\end{array}$ & $\begin{array}{l}0, \\
50\end{array}$ \\
\hline $\begin{array}{l}\text { Prodi C } \\
\text { (A3) }\end{array}$ & $\begin{array}{l}0 \\
50\end{array}$ & $\begin{array}{l}0 \\
50\end{array}$ & $\begin{array}{l}0 \\
75\end{array}$ & $\begin{array}{l}0 \\
75\end{array}$ & 1 & 1 & 1 & 1 & $\begin{array}{l}0, \\
50\end{array}$ & $\begin{array}{l}0, \\
50\end{array}$ & $\begin{array}{l}0, \\
50\end{array}$ & $\begin{array}{l}0 \\
50\end{array}$ & 0 & 0,50 & $\begin{array}{l}0, \\
50\end{array}$ & $\begin{array}{l}0 \\
50\end{array}$ & $\begin{array}{l}0, \\
50\end{array}$ \\
\hline
\end{tabular}

Matrix keputusan X diambil berdasarkan data tiga program studi seperti dibawah ini:

$\mathrm{X}=$

$\left[\begin{array}{ccccccccccccccccc}0,75 & 0,50 & 0,75 & 0,75 & 1 & 0,50 & 1 & 0,25 & 0,50 & 0,50 & 0,50 & 1 & 0,50 & 0,50 & 0,50 & 0,50 & 0,50 \\ 0,50 & 0,50 & 0,75 & 0,75 & 1 & 0,50 & 0,50 & 0,50 & 0,50 & 0,50 & 0,50 & 1 & 0,50 & 0,50 & 0,50 & 0,50 & 0,50 \\ 0,50 & 0,50 & 0,75 & 0,75 & 1 & 1 & 1 & 1 & 0,50 & 0,50 & 0,50 & 0,50 & 0 & 0,50 & 0,50 & 0,50 & 0,50\end{array}\right]$

\section{Menentukan Normalisasi Matriks ( R )}

Berdasarkan hasil perhitungan normalisasi matriksX, maka dapat ditentukan matriks ternormalisasi $\mathrm{R}$ sebagai berikut:

$\mathrm{R}=$

$$
\left[\begin{array}{ccccccccccccccccc}
1 & 1 & 1 & 1 & 0,25 & 0,50 & 0,25 & 1 & 1 & 1 & 1 & 1 & 1 & 1 & 1 & 1 & 1 \\
0,66 & 1 & 1 & 1 & 0,25 & 0,50 & 0,50 & 0,50 & 1 & 1 & 1 & 1 & 1 & 1 & 1 & 1 & 1 \\
0,66 & 1 & 1 & 1 & 0,25 & 0,25 & 0,25 & 0,25 & 1 & 1 & 1 & 0,50 & 0 & 1 & 1 & 1 & 1
\end{array}\right]
$$

UNITEX Vol 11 No.2 Juli - Desember 2018 | p-ISSN 2089-3957 | e-ISSN 2580-2585 


\section{Proses Perangkingan}

Proses berikutnya yaitu melakukan perangkingan terhadap alternatif (Vi). Untuk mendapatkan proses perangkingan yaitu dengan cara mengalikan vektor bobot (W) dengan matrik ternormalisasi (R). Setelah dilakukan proses perangkingan seperti perhitungan yang dilakukan diatas, maka urutan perangkingan dari nilai terbesar adalah didapat hasil sebagai berikut, V1 (A1) $=12,50 ; \mathrm{V} 2(\mathrm{~A} 2)=12,04 ; \mathrm{V} 3(\mathrm{~A} 3)=10,16$.

Tabel 5. Perangkingan alternatif secara manual

\begin{tabular}{|c|c|c|}
\hline Alternatif & Keterangan & Ranking \\
\hline A1 & Program Studi A & Ranking - 1 \\
\hline A2 & Program Studi B & Ranking - 2 \\
\hline A3 & Program Studi C & Ranking - 3 \\
\hline
\end{tabular}

\section{Rancangan Sistem Secara Global}

Rancangan sistem yang akan diaplikasikan ini bertujuan untuk memberikan gambaran secara umum kepada pengguna tentang sistem yang akan dibangun dan mendefinisikan komponen-komponen sistem yang akan didesain secara rinci. Tujuan rancangan sistem evaluasi kinerja program studi ini yaitu untuk membantu para pengambil keputusan untuk menentukan program sehingga dapat menentukan peringkat dari masing-masing program studi.

a. Use Case Evaluasi Kinerja Prodi

Gambar use case system evaluasi kinerja prodi terdapat pada gambar dibawah ini: 


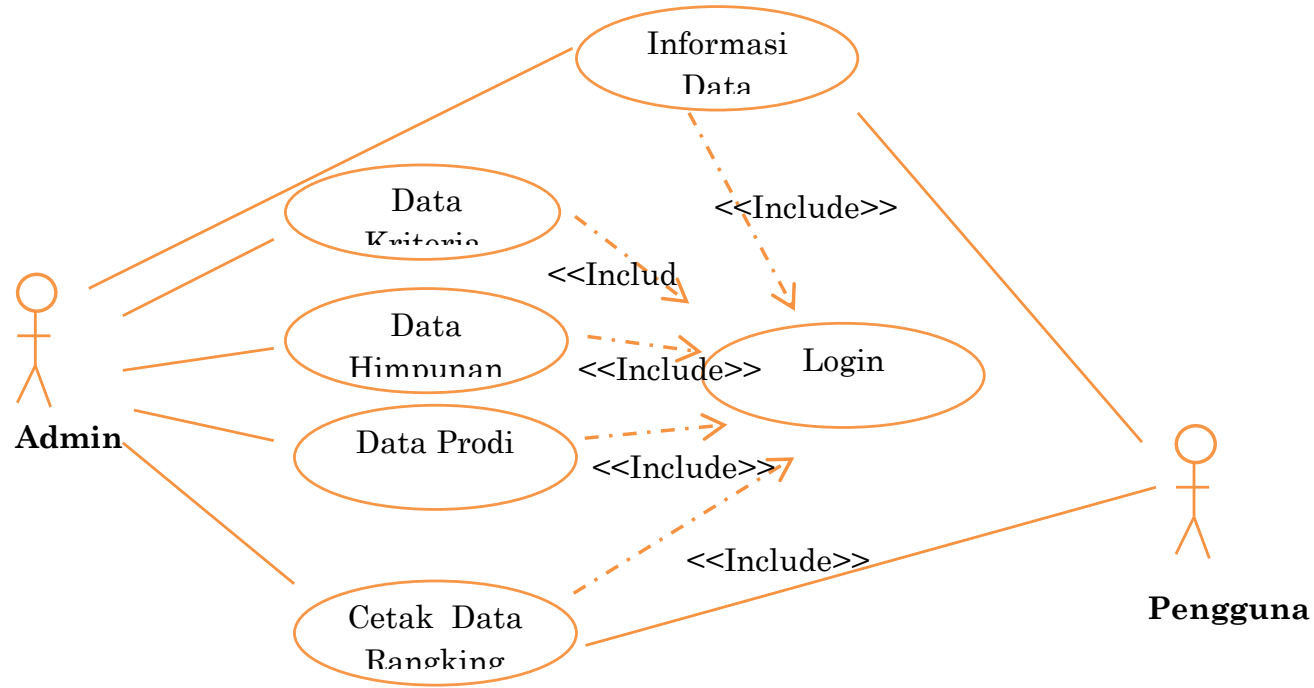

Gambar 3. Use case diagram kinerja program studi

b. Class Diagram

Adapun rancangan class diagram dari sistem evaluasi kinerja program studi sebagai berikut:

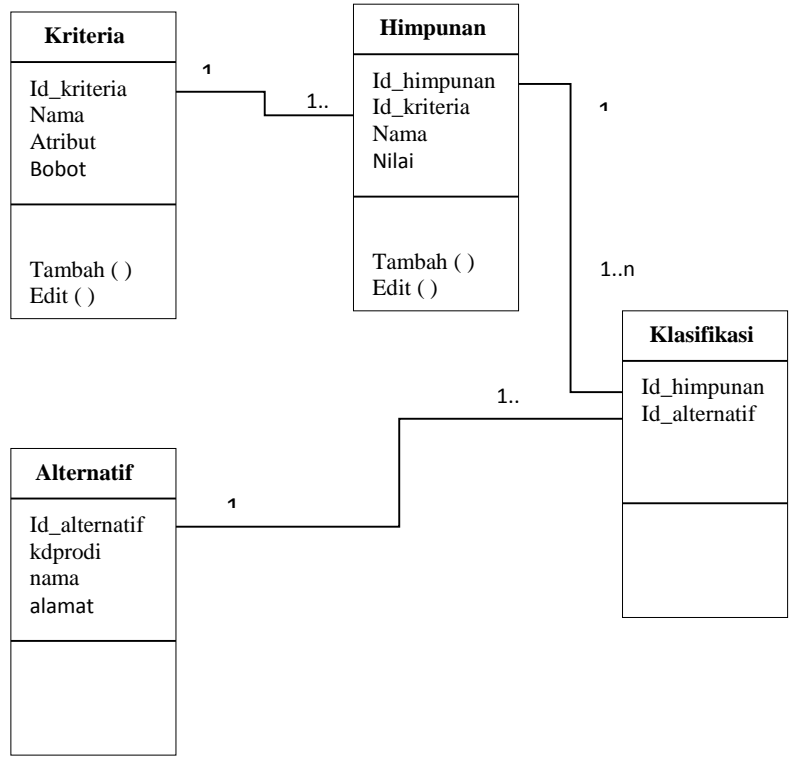

Gambar 4. Class diagram kinerja program studi

UNITEX Vol 11 No.2 Juli - Desember 2018 | p-ISSN 2089-3957 | e-ISSN 2580-2585 
c. Sequence Diagram

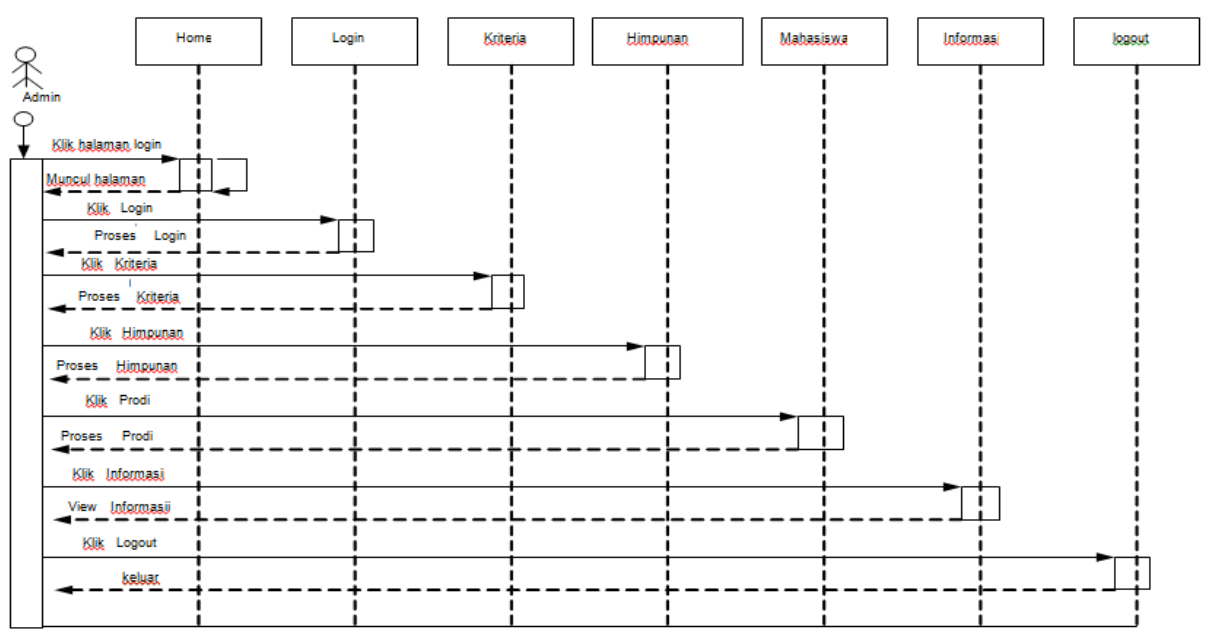

Gambar 5. Sequence diagram admin

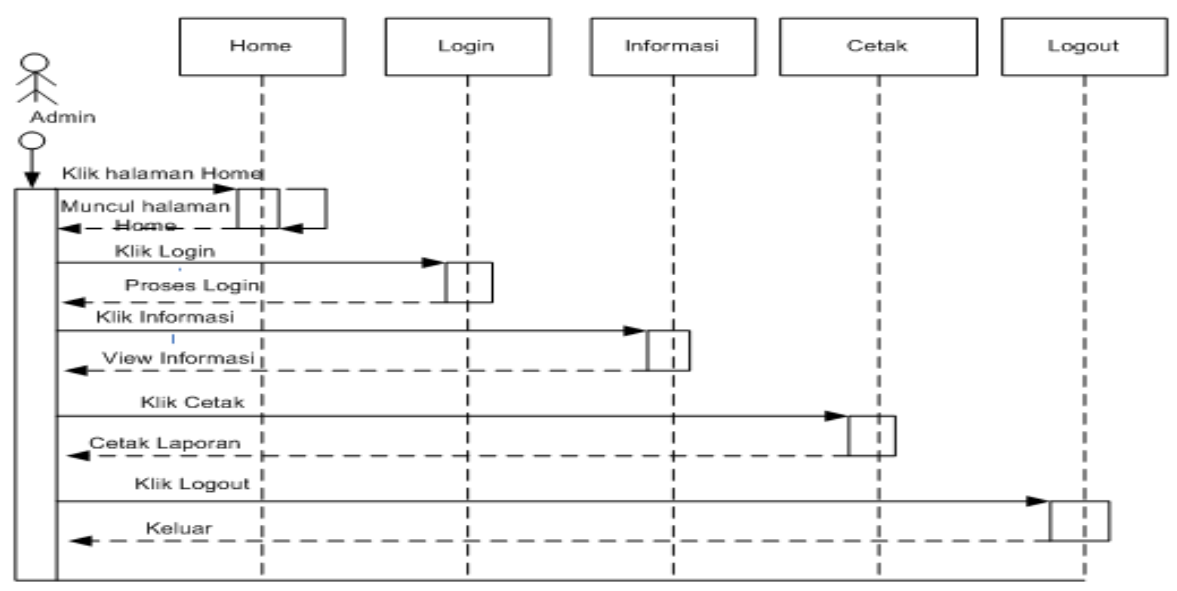

Gambar 6. Sequence diagram pengguna

d. Entity Relationship Diagram

Berikut bentuk Entity Relationship Diagram evaluasi kinerja program studi:

UNITEX Vol 11 No.2 Juli - Desember 2018 | p-ISSN 2089-3957 | e-ISSN 2580-2585 


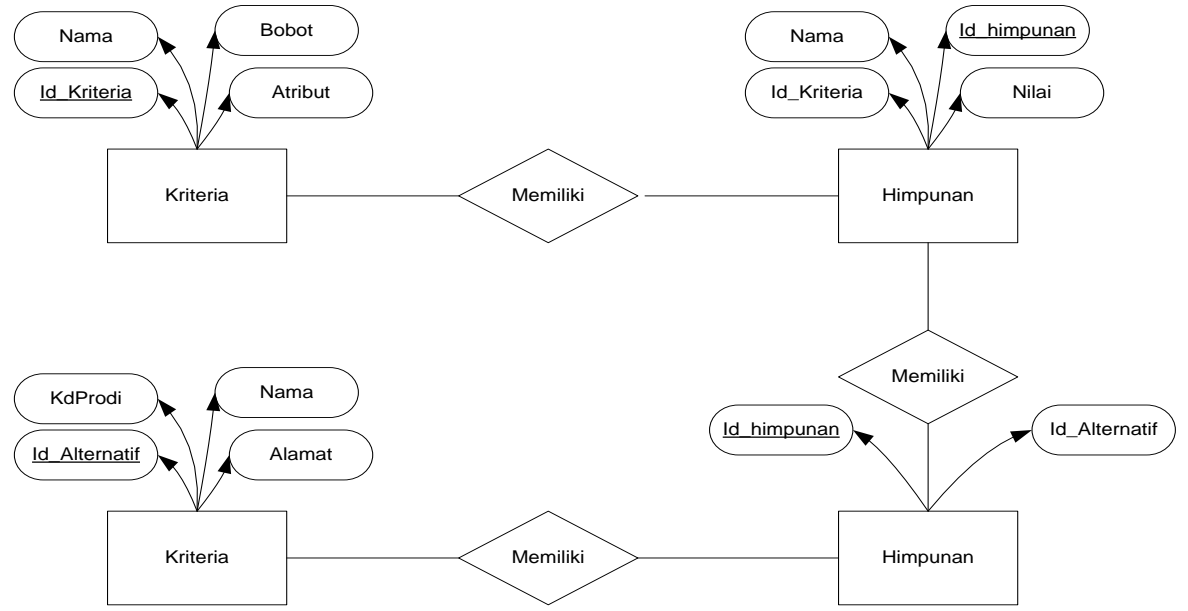

Gambar 7. Entity relationship diagram

\section{Implementasi dalam sistem informasi berbasis web}

a. Halaman Utama Sistem Informasi Kinerja Program Studi

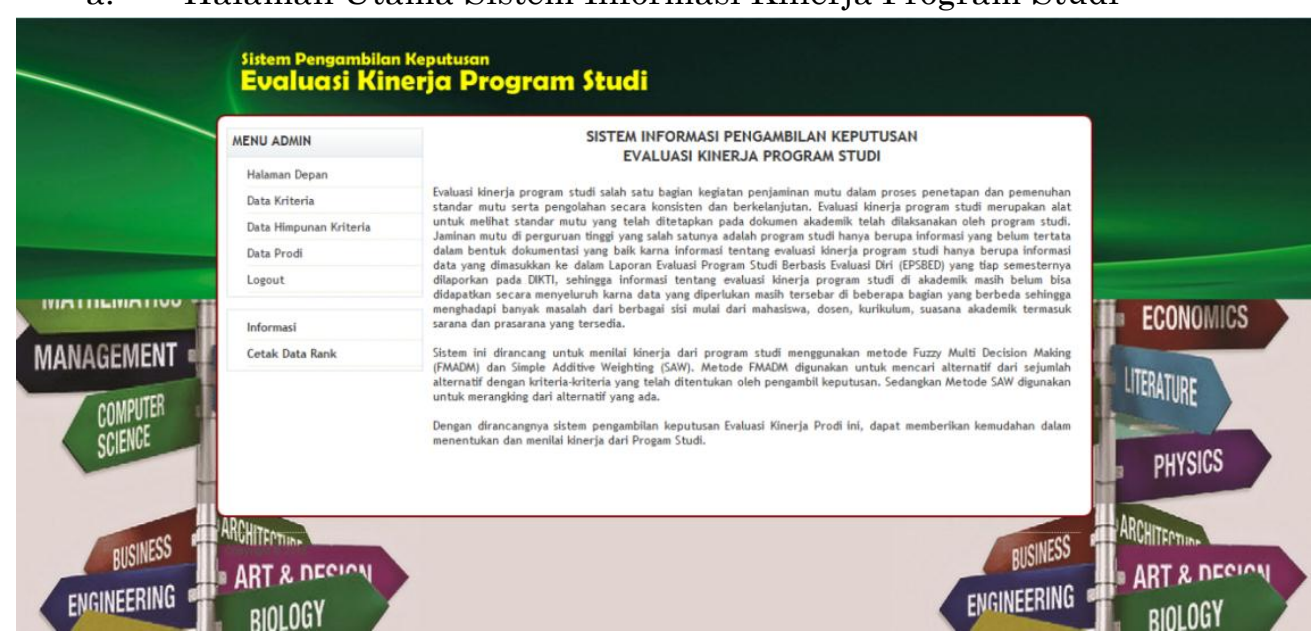

UNITEX Vol 11 No.2 Juli - Desember 2018 | p-ISSN 2089-3957 | e-ISSN 2580-2585 
b. Halaman Login

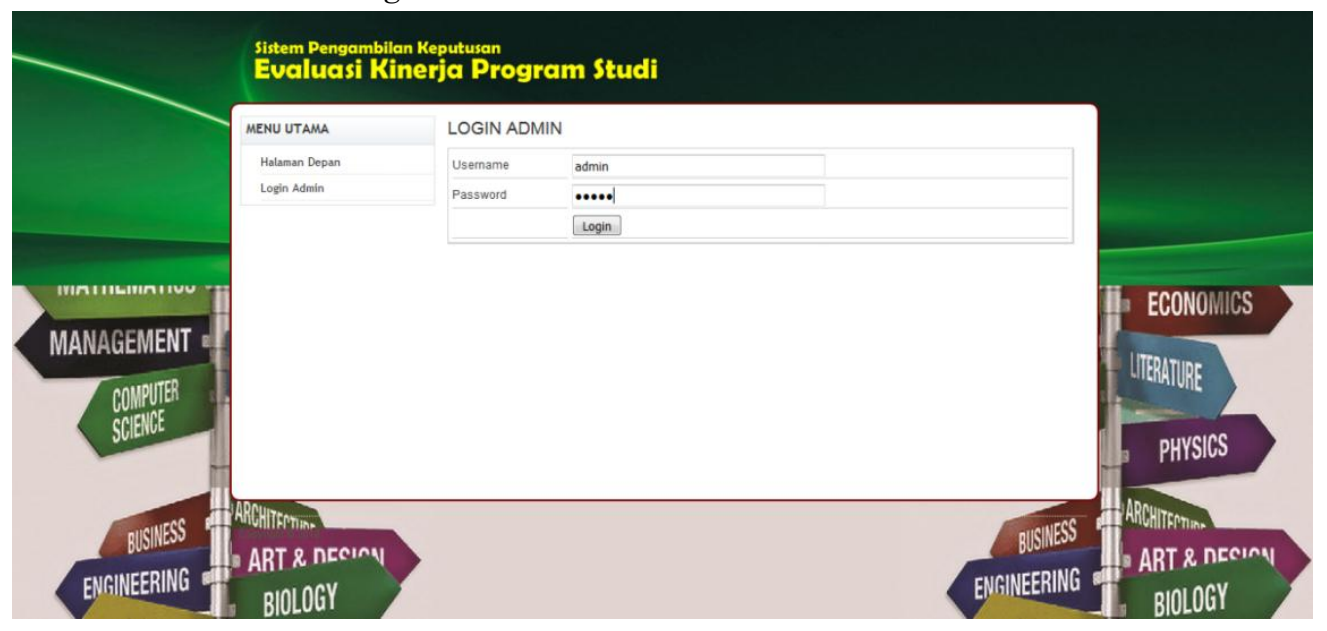

c. Halaman Admin

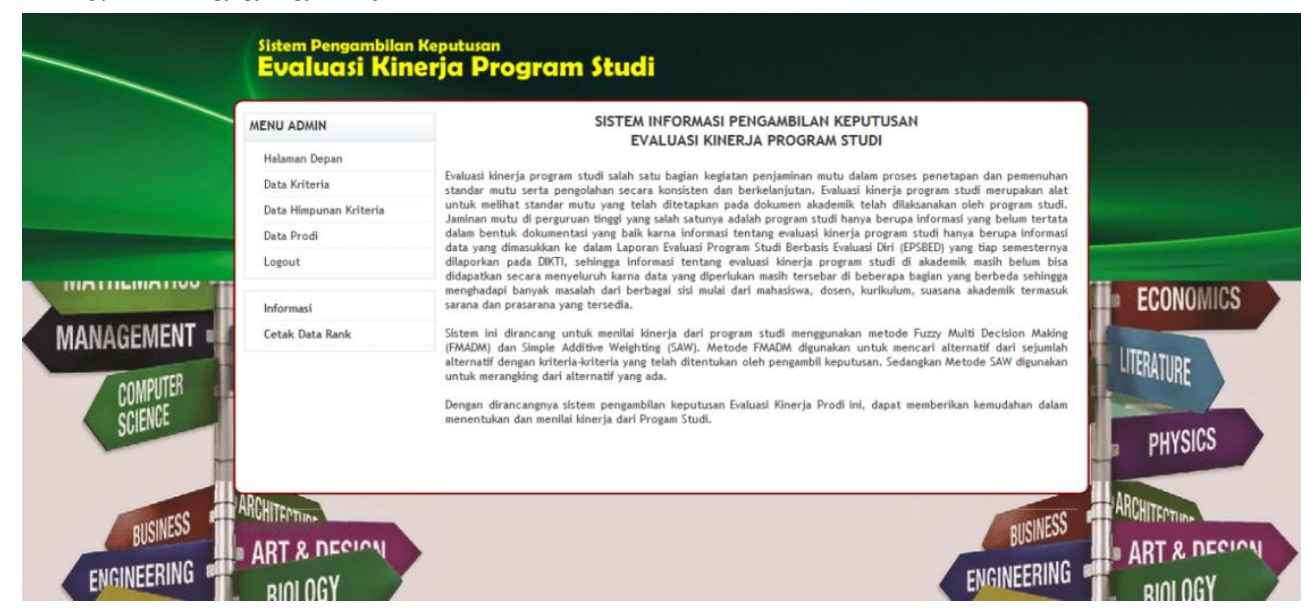

UNITEX Vol 11 No.2 Juli - Desember 2018 | p-ISSN 2089-3957 | e-ISSN 2580-2585 
d. Data Kriteria

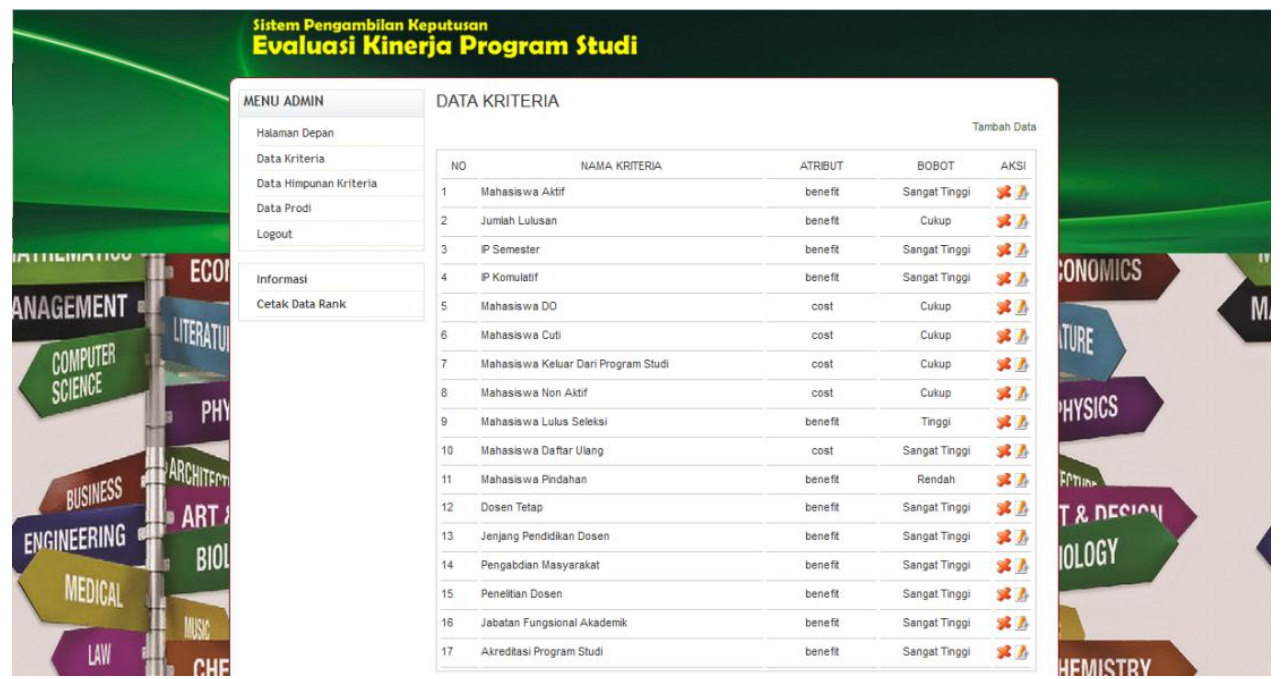

e. Data Himpunan

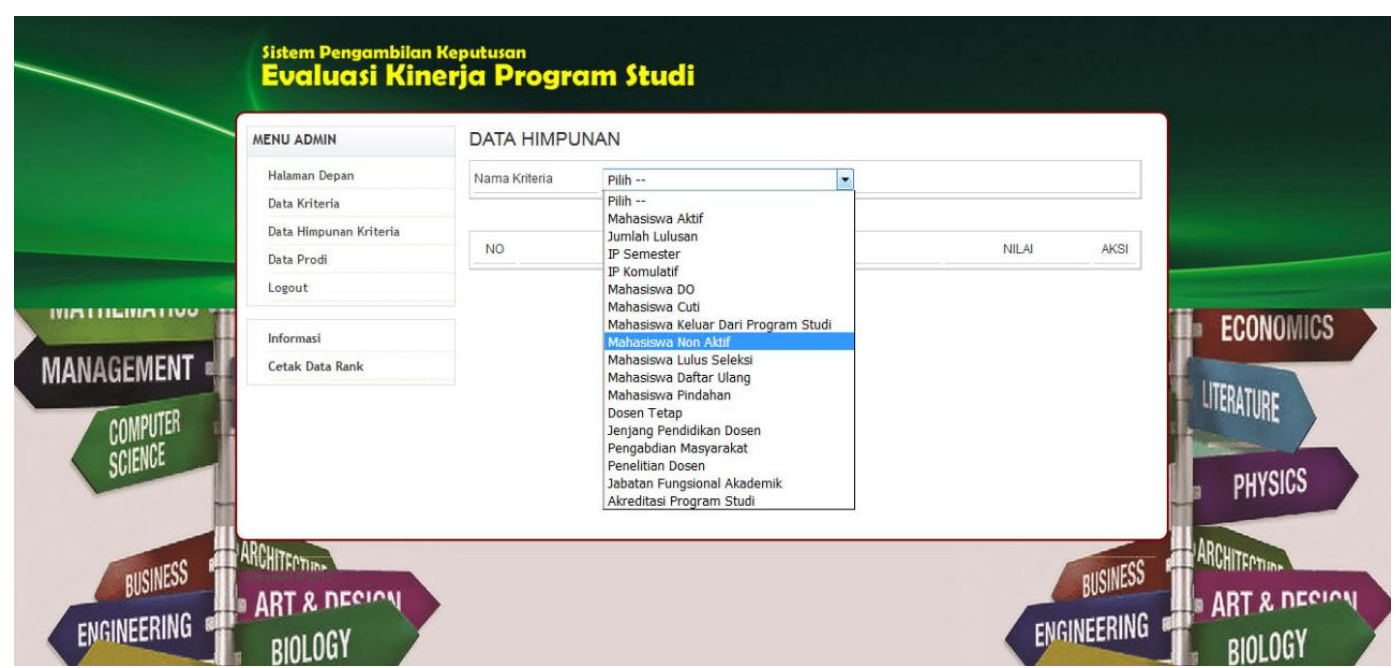

UNITEX Vol 11 No.2 Juli - Desember 2018 | p-ISSN 2089-3957 | e-ISSN 2580-2585 
f. Data Program Studi sebagai Alternatif

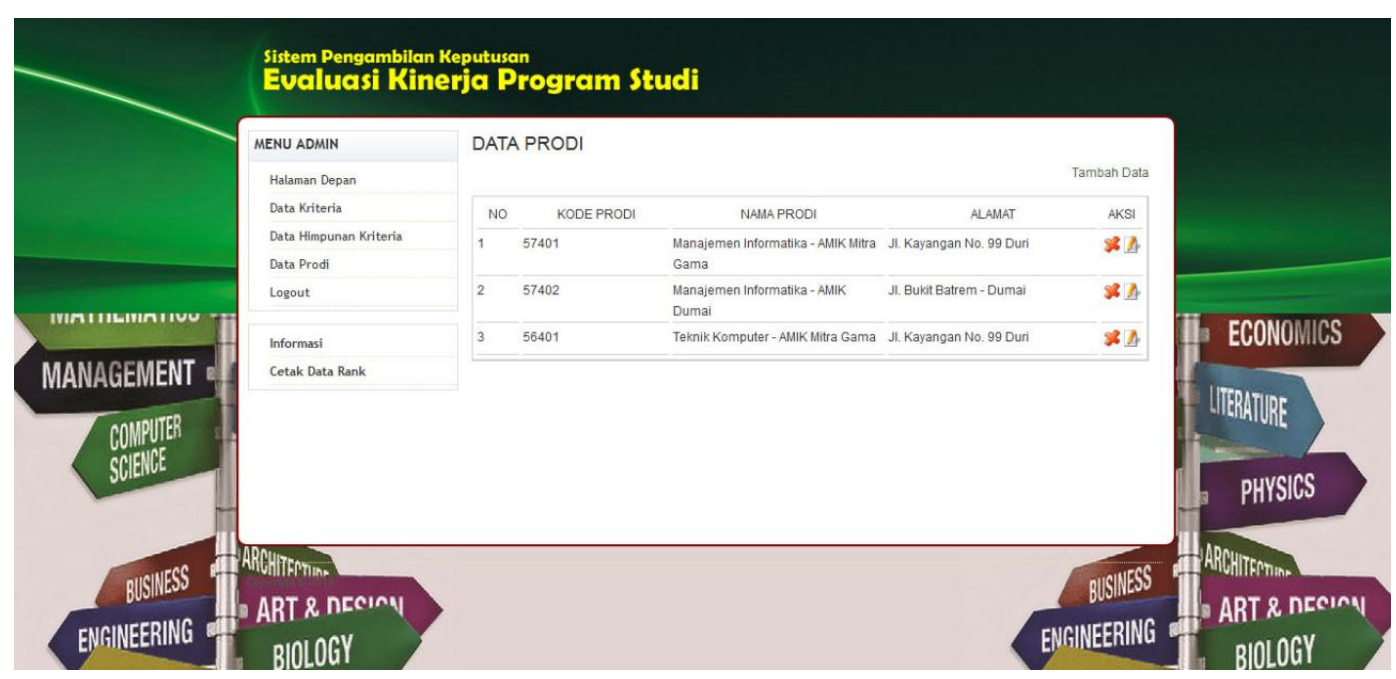

\section{Simpulan}

Setelah dilakukan Analisa dan perancangan sistem menggunakan Fuzzy Multiple Attribute Decision Making (Fuzzy MADM) dalam evaluasi kinerja program studi menggunakan metode Simple Additive Weighting (SAW), maka dapat disimpulkan berdasarkan pengujian yang telah dilakukan untuk setiap fungsi logika Fuzzy MADM metode Simple Additive Weighting (SAW), menunjukkan bahwa hasil perhitungan logika fuzzy dari sistem telah sesuai dengan hasil perhitungan manual, sehingga dapat dinyatakan bahwa aplikasi telah behasil mengimplementasi logika Fuzzy MADM metode SAW dengan baik. Menggunakan Fuzzy MADM dan menggunakan metode Simple Additive Weighting (SAW) dapat membantu dalam melakukan perangkingan evaluasi kinerja program studi berdasarkan hasil penilaian tertinggi. adanya perancangan sistem evaluasi kinerja program studi berbasis web dapat dijadikan sebagai pendukung keputusan oleh perguruan tinggi dalam melakukan evaluasi program studi secara berkala.

\section{Daftar Pustaka}

Armadyah Amborowati, "Sistem Penunjang Keputusan Pemilihan Perumahan dengan metode AHP menggunkan Expert Choice ":Jurnal

UNITEX Vol 11 No.2 Juli - Desember 2018 | p-ISSN 2089-3957 | e-ISSN 2580-2585 
Chr. Jimmy L. Gaol (2008)."Sistem Informasi Manajemen Pemahaman dan Aplikasi" Cetakan pertama. Jakarta : Grasindo.

Elisa Mengkepe (2004) "SPK Kredit Mobil PT. Astra International Tbk. Isuzu Division Makasar" Universitas Widyatama.

Fitra Amir, Sartana (2011) "Analisis Perancangan Sistem Pendukung Keputusanmenggunakan Simple Additive Weighting Untuk Seleksi Penerimaan Mahasiswa Bidik Misi” Universitas Sumatera Utara : Skripsi

Fitria,Indah Fitriana (2008) "Sistem Penunjang Keputusan Pemenang Tender Proyek Menggunakan Metode AHP”. Prosiding :Jurnal

Henri Wibowo S., Amalia, Riska., Fadlun, Andi M., Arivanty, Kurnia. (2009). Sistem Pendukung Keputusan Untuk Menentukan Penerima Beasiswa BANK BRI Menggunakan FMADM (SNATI 2009) : Jurnal

Kusrini. (2007)."Konsep dan Aplikasi Sistem Pendukung Keputusan" STMIKAmikom Yogyakarta. Andi Publisher.

Merry Agustina, M.Izman Herdiansyah, Diana. (2010). "Penerapan Logika Fuzzy Multi Attribute Decision Making Dalam menentukan Nilai Kinerja Dosen Universitas Bina Darma” : Jurnal

Riki Andi Syahputra. (2011). "Sistem Pendukung Keputusan Untuk Penentuan Penerima Basiswa Menggunakan Metode Fuzzy Multiple Attribute Decision Making Pada SMA Taman Siswa Sawit Seberang”. Universitas Sumatera Utara : Skripsi

Sri Kusumadewi, Sri Hartati, Agus HarjokoWardoyo, Retantyo. (2006). "Fuzzy MultiAttribute Decision Making (Fuzzy MADM)" .Cetakan Pertama. Yogyakarta: Graha Ilmu.

Sri Eniyati. (2011). Perancangan Sistem Pendukung Pengambilan Keputusan Untuk Penerimaan Mahasiswa Dengan Metode SAW (Simple Additive Weighting) (ISSN: 0854-9524) “: Jurnal

Widya Nita Maria Simamora (2011) "Pendukung Keputusan Untuk Manajemen Resiko Kredit Berbasis WEB Dngan Menggunakan TOPSIS”. Universitas Sumatera Utara: Skripsi

UNITEX Vol 11 No.2 Juli - Desember 2018 | p-ISSN 2089-3957 | e-ISSN 2580-2585 